\title{
GAMBARAN MOTIVASI KERJA PADA KARYAWAN AIRPORT COMPANY
}

\author{
Lisma Aisyatul Azizah ${ }^{1}$, Anissa Lestari Kadiyono² \& Marina Sulastiana ${ }^{3}$ \\ Fakultas Psikologi, Universitas Padjadjaran \\ lismaazizah@gmail.com
}

\begin{abstract}
The study is conducted to figure out employees' motivation level in an airport company in Indonesia. Motivation was measured with self-report questionnaire based on Vroom's motivation theory. The questionnaire is comprised of 52 items, filled-out by 73 participants. Result shows that $54 \%$ employees has a moderate level of motivation. Valence gives the highest contribution for employee motivation, followed by expectancy, and instrumentality, which means that reward is an essential factor in shaping employees' motivation. Demographic factors such as gender, age, managerial level, and education did not contribute to differences in motivation score among employees, therefore demographic factors are not essential in shaping employees' motivation in airport company.
\end{abstract}

Keywords: Airport Company, Expectancy, Instrumentality, Motivation, Valence

\begin{abstract}
ABSTRAK
Penelitian ini dilakukan untuk mengetahui tingkat motivasi karyawan pada salah satu perusahaan pengelolaan bandara di Indonesia. Instrumen alat ukur yang digunakan adalah kuesioner motivasi kerja yang diturunkan dari teori motivasi Victor H. Vroom. Kuesioner yang berisi 52 item diisi secara self-report oleh 73 karyawan tetap. Hasil penelitian menunjukkan bahwa 54\% karyawan memiliki tingkat motivasi yang moderat. Hasil perhitungan statistik menunjukkan bahwa tidak terdapat perbedaan signifikan skor motivasi pada laki-laki dan perempuan. Dimensi yang paling berkontribusi terhadap motivasi kerja karyawan adalah dimensi valence diikuti dengan dimensi expectancy, dan instrumentality. Hal ini menunjukkan bahwa reward menjadi faktor penting dalam membentuk motivasi karyawan. Jenis kelamin, usia, level jabatan, dan tingkat pendidikan tidak memberikan kontribusi terhadap perbedaaan skor motivasi pada setiap kelompok yang menunjukkan bahwa motivasi karyawan tidak dipengaruhi oleh faktor - faktor demografis.
\end{abstract}

Kata Kunci: Airport Company, Expectancy, Instrumentality, Motivasi, Valence 


\section{PENDAHULUAN}

Pada era perdagangan bebas dan terbuka, infrastruktur yang memadai menjadi salah satu syarat dalam proses pertukaran barang dan jasa. Selain infrastruktur darat, transportasi udara juga menjadi salah satu layanan penting untuk percepatan proses distribusi barang dan jasa. Keberadaan bandara internasional dan maskapai penerbangan yang memiliki pelayanan berkualitas menjadi kebutuhan setiap negara. Aiport minimum requirement menjadi acuan bandara untuk memenuhi standar internasional dan menjadi penghubung negara - negara di dunia.

Pengelolaan infrastruktur dan transportasi dilakukan oleh perusahaan pengelola bandara. Di Indonesia, perusahaan pengelola bandara pada umumnya merupakan badan usaha milik negara/daerah maupun perusahaan swasta. Dinamika perubahan kebutuhan konsumen terhadap pelayanan bandara yang memuaskan menjadi tantangan bagi karyawan untuk bisa menyediakan layanan jasa dan fasilitas yang memadai. Pembangunan bandara baru juga terus dilakukan di Indonesia untuk mendukung keterhubungan antardaerah. Daerah yang saat ini baru saja membuka bandara - bandara baru diantaranya mencakup Jawa Barat, Bali Utara, Samarinda, dan D.I. Yogyakarta. Bandara - bandara tersebut baru beroperasi antara kisaran tahun 2017 - 2019 . Melalui pembangunan bandara baru, diharapkan transportasi udara semakin berkembang dan mendukung bisnis serta pariwisata wilayah setempat.

Pada dasarnya, perusahaan pengelola bandara menjadi penyedia layanan bandara sehingga dapat memenuhi kebutuhan penumpang. Perusahaan bekerja dengan mitra bisnis dan maskapai penerbangan untuk dapat memenuhi kebutuhan transportasi bagi konsumen. Oleh karena itu, pelayanan menjadi salah satu kunci bisnis dalam mengelola bandara. Performa sumber daya manusia perusahaan dalam memberikan layanan, merupakan kunci untuk menghasilkan pelayanan yang baik bagi konsumen (Shahzad, 2018). Karyawan turut membentuk persepsi karyawan 
terhadap perusahaan melalui perilaku dan tindakan yang mereka tampilkan (Shahzad, 2018). Karyawan yang termotivasi untuk memberikan pelayanan, akan memberikan dampak positif terhadap layanan yang diterima konsumen. Motivasi karyawan dapat terbentuk dari adanya penilaian karyawan terhadap outcome yang dapat dihasilkan dan reward yang mengikuti outcome tersebut (Lee, 2011). Karyawan dapat menilai apakah usaha yang dilakukannya dapat menghasilkan outcome yang diharapkan. Karyawan juga menilai sejauh mana ia yakin bahwa outcome tersebut dapat menghasilkan reward dan nilai dari reward tersebut bagi dirinya.

Proses kognitif bagi terbentuknya motivasi karyawan dijelaskan dalam VIE theory of motivation dari Victor H. Vroom. Vroom (1964) dalam bukunya menjelaskan bahwa motivasi merupakan model kognitif dari motivasi. Teori Motivasi Vroom melibatkan adanya penilaian karyawan terhadap upaya yang ia lakukan, outcome kerja yang bisa dihasilkan, dan reward yang didapatkan dari outcome tersebut. Pada dasarnya teori ini mengajukan bahwa motivasi adalah hasil dari kalkulasi rasional, dimana seseorang melakukan sesuatu karena mereka memang ingin melakukannya (Vroom, 1964). Vroom meyakini bahwa motivasi ditentukan oleh keyakinan inividu mengenai usaha/performa dengan hasil kerja (Kinicki \& Kreitner, 2007).

Expectancy adalah kemungkinan yang dipersepsikan oleh individu bahwa hasil kerja akan diikuti oleh tingkat pencapaian performa tertentu (Schemerhorn, Hunt, Osborn, \& Uhl-Bien, 2010). Vroom (dalam Lee, 2007) menyebutkan bahwa expectancy merupakan keyakinan sementara yang diikuti oleh outcome tertentu. Expectancy akan sama dengan 0 jika seseorang merasa tidak mungkin mencapai level performa yang telah diberikan dan akan sama dengan +1 jika seseorang meyakini bahwa performa dapat dicapai (Schemerhorn, Hunt, Osborn, \& Uhl-Bien, 2010). 
Instrumentality adalah persepsi seseorang mengenai kemungkinan bahwa performa akan mengarahkannya pada outcome spesifik tertentu (Lee, 2007). Hal ini berkaitan dengan keyakinan atau ekspektasi individu bahwa ia berperilaku dengan cara tertentu Instrumentality bervariasi dari -1 sampai dengan 1 (Schemerhorn, Hunt, Osborn, \& Uhl-Bien, 2010). Instrumentality dapat bernilai negatif jika seseorang meyakini bahwa outcome bisa dicapai tanpa perlu menampilkan performa dan bernilai +1 jika ia meyakini bahwa peforma merupakan hal yang diperlukan dan cukup untuk menghasilkan outcome (Vroom, 1964).

Valence adalah nilai yang diberikan individu terhadap berbagai hasil kerja yang dihasilkan. Valence digambarkan sebagai orientasi afektif terhadap outcome pekerjaan (Vroom, 1964; Lee, 2007). Vroom (1964) menggambarkan bahwa kekuatan dari keinginan seseorang didasarkan pada antisipasi terhadap kepuasan yang diasosiasikan dengan outvome tertentu. Dalam hal ini, rentang skala valence adalah dari -1 (very undesirable outcome) sampai dengan +1 (very desirable outcome) (Schemerhorn, Hunt, Osborn, \& Uhl-Bien, 2010). Valence bernilai positif ketika seseorang memilih untuk menghasilkan outcome tertentu; bernilai 0 ketika seseorang tidak bisa memutuskan untuk menghasilkan atau tidak menghasilkan outcome tertentu; dan bernilai negatif ketika seseorang memutuskan untuk tidak berusaha menghasilkan outcome yang dituju (Vroom, 1964).

Penelitian ini dilakukan kepada karyawan salah satu perusahaan pengelola bandara di Indonesia. Perusahaan ini tergolong baru didirikan dan diproyeksikan untuk menggenjot roda perekonomian wilayah sekitar. Gambaran mengenai proses motivasi karyawan di perusahaan dapat memberikan insight mengenai hal - hal yang bisa ditingkatkan oleh perusahaan pengelola bandara terhadap motivasi karyawan.

\section{METODE PENELITIAN}


Variabel dalam penelitian ini adalah motivasi kerja. Motivasi kerja didefinisikan sebagai hasil dari kalkulasi rasional, dimana seseorang terdorong untuk melakukan sesuatu karena keyakinan inividu mengenai usaha/performa dengan hasil kerja yang didapatkan (Vroom, 1964). Secara operasional, definisi kerja dapat diartikan sebagai dorongan bagi karyawan untuk menampilkan usaha atau performa yang diharapkan dengan didasarkan pada 3 komponen, yaitu:

a. Expectancy, mencakup penilaian karyawan bahwa usaha yang ia berikan untuk menyelesaikan pekerjaan akan menghasilkan tingkat performa tertentu.

b. Instrumentality, mencakup penilaian karyawan bahwa perfoma yang ia tampilkan akan memberikan reward.

c. Valence, penilaian terhadap reward yang diterima pegkaryawanatas usahanya dalam menyelesaikan tugas.

Selanjutnya motivasi merupakan dinamika dari ketiga komponen tersebut yang dihasilkan dari perkalian aspek - aspek, yaitu expectancy, instrumentality, dan valence. Semakin tinggi hasil perkalian menunjukkan motivasi kerja yang lebih tinggi, dan sebaliknya jika hasil perkalian rendah maka menunjukkan motivasi kerja yang rendah.

Penelitian ini melibatkan seluruh karyawan tetap di sebuah perusahaan pengelola bandara. Kuesioner disebarkan kepada 88 orang karyawan tetap dan terdapat 73 kuesioner yang dikumpulkan kembali kepada peneliti. Penelitian juga melibatkan seluruh level jabatan mulai dari kepala divisi, kepala departemen, kepala seksi, dan staff. Data demografi partisipan penelitian diuraikan pada tabel berikut: 
Tabel 1. Data Demografi Partisipan

\begin{tabular}{cccc}
\hline DEMOGRAFI & KATEGORI & N & \% \\
\hline \multirow{2}{*}{ Gender } & Laki - Laki & 45 & $61.6 \%$ \\
& Perempuan & 28 & $38.4 \%$ \\
\hline \multirow{3}{*}{ Usia } & $21-30$ tahun & 49 & $67.1 \%$ \\
& $31-40$ tahun & 16 & $21.9 \%$ \\
& $40-50$ tahun & 7 & $9.6 \%$ \\
\multirow{3}{*}{ Tingkat Pendidikan } & $>50$ tahun & 1 & $1.4 \%$ \\
& SMA & 2 & $2.7 \%$ \\
& D3 & 11 & $15.1 \%$ \\
Level Jabatan & D4/S1 & 50 & $68.5 \%$ \\
& S2 & 10 & $13.7 \%$ \\
& Kepala Divisi & 6 & $8.20 \%$ \\
& Kepala Departemen & 6 & $8.20 \%$ \\
Lepala Seksi & 14 & $64.2 \%$ \\
& Staf & 47 & $5.5 \%$ \\
\hline \multirow{3}{*}{ Bekerja } & $0-1$ tahun & 4 & $52.1 \%$ \\
& $1-2$ tahun & 38 & $26.0 \%$ \\
& $3-4$ tahun & 19 & $16.4 \%$ \\
\hline
\end{tabular}

Alat ukur penelitian ini menggunakan kuesioner self-report yang dikembangkan dari expectancy theory. Terdapat 52 item pernyataan, dengan rincian dimensi expectancy sebanyak 19 item, dimensi instrumentality 17 item, dan dimensi valence 16 item. Alat ukur ini menggunakan skala Likert dari 1 - 6. Skor motivasi kerja merupakan hasil perkalian dari skor ketiga dimensi expectancy, instrumentality, dan valence. Reliabilitas alat ukur motivasi kerja diukur dengan menggunakan metode internal consistency (cronbach $\alpha$ ). Hasil perhitungan menggunakan perangkat lunak SPSS 2.0 for Windows menunjukkan nilai cronbach $\alpha$ untuk alat ukur motivasi kerja sebesar 0.887. Nilai ini menunjukkan bahwa reliabilitas alat ukur tergolong tinggi dan dapat diandalkan untuk mengukur motivasi kerja pada karyawan.

Pengolahan data statistik deskriptif dilakukan untuk mengetahui gambaran umum data motivasi kerja pada karyawan. Pengolahan data statistik juga dilakukan untuk mengetahui perbedaan skor pada kelompok gender dan level jabatan. Teknik statistik yang digunakan adalah 
Independent Sample T-Test dan One-Way ANOVA. Pada penelitian ini pengolahan data statistik dilakukan dengan bantuan perangkat lunak SPSS for Windows.

\section{HASIL PENELITIAN}

Skor motivasi karyawan didapatkan dari hasil perkalian rata - rata skor dimensi expectancy, instrumentality, dan valence. Normalitas data diuji dengan uji Kolmogorov-Smirnov, dimana hasilnya menunjukkan bahwa data berdistribusi normal. Selanjutnya, dilakukan uji beda dengan menggunakan $T$ - dan One-Way ANOVA untuk mengetahui signifikansi perbedaan skor motivasi pada kelompok jenis kelamin dan level jabatan. Berdasarkan skor total, motivasi karyawan dikategorikan ke dalam kategori rendah, sedang, dan tinggi. Hasil perhitungan menunjukkan bahwa sebanyak 3.4\% karyawan (3 orang) memiliki motivasi yang tergolong tinggi, 54.74\% karyawan (54 orang) memiliki motivasi yang tergolong sedang (moderat), dan 16.22\% (16 orang) karyawan tergolong memiliki motivasi yang rendah.

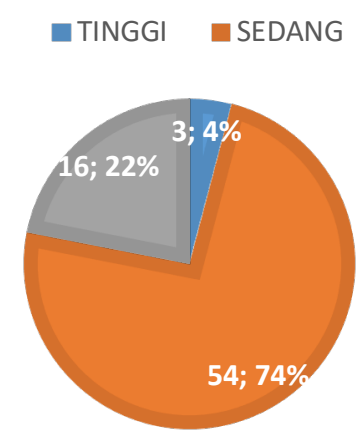

\section{Grafik 1. Motvasi Karyawan}

Sebagian besar karyawan memiliki tingkat motivasi yang moderat. Hal ini menunjukkan bahwa karyawan masih bersedia menampilkan usahanya untuk menyelesaikan tugas - tugas yang diberikan dalam rangka mencapai target yang diberikan. Penjelasan mengenai hal tersebut dapat didukung dengan skor rata - rata untuk setiap dimensi motivasi yang ditunjukkan pada tabel berikut: 


\section{Tabel 2. Skor Rata - Rata Dimensi Motivasi}

\begin{tabular}{cc}
\hline DIMENSI & MEAN \\
\hline Expectancy & 4.83 \\
\hline Instrumentality & 4.08 \\
\hline Valence & 4.92 \\
\hline
\end{tabular}

Hasil uji One-Way ANOVA terhadap rata - rata skor ketiga dimensi menunjukkan terdapat perbedaan signifikan antara skor dimensi expectancy, instrumentality, dan valence dengan $\mathrm{p}<0.05$ $[\mathrm{F}(2,216)=84.52, \mathrm{p}=0.00]$. Dimensi dengan skor rata - rata tertinggi adalah dimensi valence $(\mathrm{M}$ =4.92), diikuti dengan dimensi expectancy $(\mathrm{M}=4.83)$, dan instrumentality $(\mathrm{M}=4.08)$. Hal ini menunjukkan bahwa dimensi valence merupakan dimensi yang paling berkontribusi terhadap motivasi karyawan. Dimensi yang rata - ratanya paling kecil adalah dimensi instrumentality. Data ini menunjukkan bahwa karyawan belum sepenuhnya yakin bahwa hasil kerja yang ia berikan bisa membawanya pada reward tertentu bagi perusahaan.

Uji beda menggunakan Independent Sample T-Test dilakukan terhadap skor motivasi kerja antara kelompok jenis kelamin laki - laki dan perempuan. Hasil uji beda skor motivasi antara laki - laki dan perempuan, menunjukkan bahwa tidak terdapat perbedaan signifikan antara skor motivasi karyawan laki - laki $(\mathrm{M}=99.78, \mathrm{SD}=30.72)$ dan skor motivasi karyawan perempuan $(\mathrm{M}=97.68, \mathrm{SD}=24.72) ; \mathrm{t}(73)=0.305, \mathrm{p}=0.762$. Hal ini menunjukkan bahwa faktor demografi jenis kelamin/gender tidak memberikan kontribusi terhadap perbedaan skor motivasi karyawan.

Uji beda juga dilakukan terhadap skor motivasi berdasarkan level jabatan (kepala divisi, kepala departemen, kepala seksi, dan staf). Uji beda dilakukan dengan menggunakan One-Way Anova. Hasil uji beda skor motivasi berdasarkan level jabatan menunjukkan bahwa tidak terdapat perbedaan signifikan antara skor motivasi kepala divisi $(\mathrm{M}=107.81, \mathrm{SD}=16.62)$, kepala departemen $(M=77.61, S D=15.94)$, kepala seksi $(M=99.03, S D=27.44)$, dan staf $(M=99.69$, 
$\mathrm{SD}=30.34)$ dengan $\mathrm{p}<0.05[\mathrm{~F}(3,69)=0.965, \mathrm{p}=0.419]$. Perbedaan skor motivasi pada setiap kelompok usia juga diuji signifikansinya. Berdasarkan hasil One-Way ANOVA, maka didapatkan bahwa tidak ada perbedaan signifikan skor motivasi pada keempat kelompok usia, baik itu pada kelompok usia 21 - 30 tahun, $31-40$ tahun, $40-50$ tahun, dan diatas 50 tahun dengan $\mathrm{p}<0.05$ $[\mathrm{F}(3,69)=1.831, \mathrm{p}=0.15] . \quad$ Dalam hal ini, level jabatan maupun usia tidak memengaruhi perbedaan skor motivasi pada karyawan.

Peneliti juga menguji perbedaan skor berdasarkan tingkat pendidikan karyawan. Hasil uji beda menunjukkan bahwa tidak ada perbedaan skor motivasi antara karyawan dengan tingkat pendidikan SMA $(M=77.26, \mathrm{SD}=54.97), \mathrm{D} 3(\mathrm{M}=20.78, \mathrm{SD}=6.26), \mathrm{S} 1(\mathrm{M}=29.63, \mathrm{SD}=$ 4.14), maupun $\mathrm{S} 2(\mathrm{M}=26.09, \mathrm{SD}=8.69)$ dengan $\mathrm{p}<0.05[\mathrm{~F}(3,69)=0.238, \mathrm{p}=0.70]$. Hasil tersebut menunjukkan bahwa tingkat pendidikan karyawan tidak berkontribusi terhadap adanya perbedaan skor motivasi pada karyawan.

\section{DISKUSI}

Motivasi merupakan seberapa besar usaha yang dikerahkan dalam mencapai hasil atau imbalan (Kreitner \& Knicki, 2007). Konsep motivasi dari Vroom (1964) menjelaskan bahwa motivasi terbentuk melalui 3 komponen, yaitu expectancy yang merupakan keyakinan individu bahwa usahanya akan menghasilkan performa kerja tertentu, instrumentality yang merupakan penilaian bahwa tingkat performa yang dihasilkan akan memberikan reward tertentu, dan valence yang berkaitan dengan penilaian afektif individu terhadap reward yang diterima (Vroom, 1964). Ketiga komponen tersebut memiliki nilai masing - masing dan besaran motivasi merupakan perkalian dari ketiga komponen tersebut (Vroom, 1964). Aspek expectancy bernilai positif jika individu menilai bahwa usahanya akan menghasilkan hasil kerja yang baik, sedangkan aspek instrumentality bernilai tinggi jika individu meyakini bahwa hasil kerjanya tersebut akan 
membawanya pada suatu reward tertentu. Aspek valence bernilai positif ketika individu menilai bahwa reward yang akan ia dapatkan bisa memberikan kepuasan.

Berdasarkan hasil penelitian, skor motivasi karyawan sebagian besar berada pada kategori sedang (moderate). Hal ini menunjukkan bahwa karyawan pada dasarnya masih memiliki semangat untuk menyelesaikan tugas - tugasnya dan memenuhi standar minimal dari pekerjaan. Mereka mengerjakan pekerjaan yang diberikan sesuai dengan pengetahuan dan keterampilan yang dimiliki dan tidak ada keinginan untuk mencapai lebih dari target. Temuan tersebut dapat berkaitan dengan situasi khusus di perusahaan, dimana ada kebijakan penundaan program kerja karena kendala finansial perusahaan, sehingga karyawan pun merasa bahwa usaha yang dilakukannya tidak banyak berpengaruh terhadap perusahaan. Tingkat motivasi yang sedang dirasakan oleh karyawan dari berbagai level jabatan mulai dari kepala divisi, kepala departemen, kepala seksi, sampai dengan staf.

Apabila ditinjau dari masing - masing aspek, maka aspek yang paling berkontribusi pada motivasi karyawan adalah valence. Hal tersebut didukung dengan hasil uji beda terhadap ketiga dimensi motivasi - expectancy, instrumentality, dan valence yang menunjukkan bahwa terdapat perbedaan signifikan antara skor ketiga dimensi motivasi $[F(2,216)=84.52, p=0.00]$. Hasil ini menunjukkan bahwa mean dimensi memiliki makna dan dapat dibandingkan satu sama lain. Valence merupakan dimensi yang paling besar kontribusinya terhadap motivasi, disusul dengan dimensi expectancy dan dimensi instrumentality. Dimensi valence berkaitan dengan penilaian afektif karyawan terhadap reward yang bisa ia terima dari hasil kerjanya (Vroom, 1964). Reward yang diberikan dapat berbentuk kenaikan jabatan, kenaikan gaji dan tunjangan, penghargaan, pujian, dan kesempatan pengembangan diri. Valence yang tinggi menunjukkan bahwa karyawan meyakini reward yang ia terima bisa memberikan kepuasan pada dirinya. Meskipun perusahaan 
yang diteliti saat ini belum sepenuhnya dapat memberikan reward berupa kenaikan tunjangan dan kesempatan pengembangan diri yang memadai, namun karyawan merasa bahwa jika hal - hal tersebut ia dapatkan, maka ia akan merasa puas.

Dimensi expectancy dan instrumentality juga berada pada kategori tinggi. Expectancy yang cukup tinggi menunjukkan bahwa pada dasarnya karyawan yakin bahwa usaha yang ia lakukan untuk menyelesaikan tugas - tugasnya dalam mengelola bisnis bandara bisa menghasilkan outcome yang sesuai dengan harapannya. Dimensi instrumentality juga tergolong tinggi, namun lebih rendah dari dimensi lain. Apabila melihat pada kondisi perusahaan yang masih baru, belum ada sistem reward dan pengembangan diri yang memadai bagi karyawan, sehingga ketika karyawan menilai apakah hasil kerjanya bisa memberikan reward tertentu, karyawan tidak sepenuhnya merasa yakin.

Hasil uji beda skor motivasi karyawan berdasarkan jenis kelamin, menunjukkan bahwa tidak terdapat perbedaan yang signifikan antara skor motivasi karyawan laki - laki dan perempuan. Apabila dilihat dari mean skor pada masing - masing kelompok, maka skor motivasi pada kedua kelompok berada pada kategori sedang. Mean skor motivasi laki - laki $(\mathrm{M}=99.78)$ nilainya lebih tinggi dibandingkan mean skor motivasi perempuan $(M=97.68)$. Pada dasarnya perbedaan motivasi pada laki - laki dan perempuan didasari oleh stereotip gender. Menurut Meece et. al (2006), terdapat insentif yang lebih banyak bagi performa laki - laki seperti pendapatan, kebebasan, promosi, tantangan, dan realisasi diri. Hal tersebut berkaitan dengan reward yang menjadi objek pada komponen valence. Ketika perusahaan menyediakan reward tersebut, maka valence karyawan laki - laki dapat bernilai positif dan bernilai tinggi karena reward yang ada dinilai sebagai hal yang memuaskan. Pada wanita, tingkat motivasi kerja dipengaruhi oleh adanya fleksibilitas (berkaitan dengan keluarga) dan keinginan untuk menciptakan kesejahteraan ekonomi 
(Hitka, Kozubikova, \& Potkany,2017). Dalam menampilkan usaha kerja, perempuan umumnya menunjukkan lebih banyak usaha untuk asertif dan kompetitif dalam bekerja karena adanya anggapan prasangka terhadap kinerja perempuan yang kurang dari laki - laki (Hitka, Kozubikova, \& Potkany,2017). Oleh karena itu, pada dasarnya penilaian terhadap aspek VIE pada laki - laki dan perempuan cenderung sama terutama dalam hal valence, sehingga motivasi kerja antara lakilaki dan perempuan tidak jauh berbeda.

Hasil uji beda skor motivasi karyawan berdasarkan level jabatan menunjukkan bahwa tidak terdapat perbedaan signifikan antara skor motivasi pada level jabatan kepala divisi, kepala departemen, kepala seksi, dan staf. Apabila dilihat dari rata - rata skor, maka skor motivasi tertinggi adalah pada level kepala divisi, diikuti dengan kepala seksi, staf, dan kepala departemen. Meskipun signifikansi perbedaannya kecil, namun skor pada level top management tergolong tinggi. Hal tersebut dapat diakibatkan oleh pemaknaan kepala divisi terhadap pekerjaannya dan cenderung bekerja lebih keras dan lebih peduli terhadap pekerjaannya (Deal et. al., 2013). Hal ini berkaitan dengan aspek expectancy, dimana kepala divisi menilai bahwa hasil kerjanya pasti mengarah pada hasil kerja tertentu.

Perbedaan kelompok usia dan tingkat pendidikan juga tidak menjadi faktor yang membedakan skor motivasi karyawan. Hal ini senada dengan penelitian yang dilakukan Jalilvand dan Ebrahimabadi (2011) yang menemukan bahwa faktor demografi seperti usia dan pendidikan tidak berpengaruh terhadap skor motivasi karyawan. Secara umum, usia karyawan juga lebih dominan di satu kelompok usia yaitu usia 21 - 30, sehingga tingkat motivasi karyawan tidak jauh berbeda antar kelompok. 


\section{KESIMPULAN}

Berdasarkan hasil penelitian, diketahui bahwa skor motivasi karyawan di perusahaan pengelola bandara tergolong sedang (moderate), dimana hal ini menunjukkan bahwa karyawan masih memiliki semangat untuk mencapai hasil kerja yang diharapkan. Dimensi yang paling berkontribusi terhadap motivasi karyawan adalah valence, diikuti dengan dimensi expectancy, dan instrumentality. Karyawan menilai bahwa reward imbalan yang diberikan perusahaan memang penting bagi dirinya dan dapat memberikan kepuasan. Faktor seperti gender, level jabatan, tingkat pendidikan, dan usia ditemukan tidak berpengaruh terhadap tingkat motivasi karyawan, sehingga faktor demografis bukan menjadi hal yang berpengaruh pada perbedaan tingkat motivasi karyawan di perusahaan pengelola bandara yang diteliti.

Penelitian ini diharapkan dapat memberikan insight bagi perusahaan, khususnya pengelola bandara dalam meningkatkan motivasi karyawan, sehingga diharapkan pelayanan yang diberikan kepada konsumen lebih baik. Perusahaan dapat mengetahui aspek apa yang paling berkontribusi terhadap motivasi karyawan. Bagi pengembangan penelitian selanjutnya, dapat melibatkan jumlah subjek yang lebih banyak dan cakupan yang lebih luas.

\section{DAFTAR PUSTAKA}

Deal J. J., Stawiski, S., Graves, L., Gentry, W. A., Weber, T. J. (2013). Motivation at work: which matters more, generation or managerial level? Consulting Psychology Journal: Practice and Research. 65(1), $1-16$.

Eerde, W. Van, \& Henk, T. (1996). Vroom's Expectancy Models and Work-Related Criteria: A Meta-Analysis. Journal of Applied Psychology, 81(5), 575-586.

Kreitner, R., \& Kinicki, A. (2007). Organizational Behavior, Seventh Edition. New York: The McGraw-Hill Company, Inc.

Lee, S. (2007) Vroom's expectancy theory and the public library customer motivation model. Library Review. 56(9), 788 - 796. 
Hitka, M., Kozubikova, L., Potkamy, M. (2018). Education and gender-based differences in employee motivation. Journal of Business Economics and Management. 19(1), 80 - 95.

Jalilvand, M. R., Ebrahimabadi, F. (2011). The effects of demographic characteristics on employees' motivation to participate in service training courses based on modified expectancy theory. Canadian Social Science. 7(3), 150-158.

Lee, S. (2007). Vroom's expectancy theory and the public library customer motivation model. Library Review, 56(9), 788 - 796

Meece, J. L., Glienke, B. B., Burg, S. (2006). Gender and Motivation. New York: John Wiley \& Sons, Inc.

Simone, D. S. (2015) Expectancy value theory: motivating healthcare worker. American International Journal of Contemporary Research. 5(2), 19 - 23.

Vroom, V. H. (1964) Work and Motivation. New York: John Wiley \& Sons, Inc. 